\title{
Health-related behaviors and overweight: a study of Latino adolescents in the United States of America
}

\author{
Jorge Delva, ${ }^{1}$ Patrick M. O'Malley, ${ }^{2}$ and Lloyd D. Johnston ${ }^{2}$
}

Suggested citation

Delva J, O'Malley PM, Johnston LD. Health-related behaviors and overweight: a study of Latino adolescents in the United States of America. Rev Panam Salud Publica. 2007;21(1):11-20.

ABSTRACT Objectives. This study examined, by gender, differences in being overweight among ado lescents of Mexican, Puerto Rican, and other Latin American heritage who live in the United States of America, and investigated the relationships between these differences and socioeco nomic status, health-related behaviors, and family characteristics.

Methods. This cross-sectional survey study obtained and analyzed data from nationally representative samples of Latino 8th and 10th graders in the Monitoring the Future study from 1991 to $2004(\mathrm{~N}=11265)$.

Results. A higher proportion of Mexican-American girls were overweight than other Latin American girls, both before and after adjusting for many confounders. For both genders, being overweight was inversely associated with socioeconomic status and frequency of vigorous ex ercise, and positively associated with the amount of television viewing. No family characteris tic variable examined was associated with overweight.

Conclusions. Time spent exercising and time spent watching television are two potentially modifiable risk factors that, if targeted, may result in important reductions in overweight. The findings indicate the need to identify gender-and culturally-appropriate interventions that can increase physical activity and reduce sedentary activities among Latino adolescents, par ticularly in families of low socioeconomic status.

Key words Acculturation, Hispanic Americans, Mexican Americans, overweight, obesity, social class, socioeconomic factors, United States.

1 School of Social Work and Survey Research Center, Institute for Social Research, University of Michigan, Ann Arbor, Michigan, United States of America. Send correspondence and reprint requests to: Jorge Delva, School of Social Work and Survey Research Center, Institute for Social Research, University of Michigan, PO Box 1248, 426 Thompson St., Ann Arbor 48106-1248, MI, United States of America; telephone: (734) 647-9296; fax: (734) 936-0043; e-mail: jdelva@umich.edu

2 Survey Research Center, Institute for Social Research, University of Michigan, Ann Arbor, Michigan, United States of America.
Latinos have become the largest racial/ethnic minority group in the United States of America, and are expected to grow to about one-fourth of the population by the year 2050 (1). Unfortunately, the burden of disease in this growing population seems to be on the rise. The proportion of Latinos who are experiencing a range of health and socioeconomic problems is greater than ever (2-4), with obesity becoming one of the most pressing concerns. Several studies in the United States have found a greater percentage of Latino youth to be overweight and obese than non-Latino white males and females, and black males (5-7). This is troublesome for this population, not only because obesity is associated with high morbidity and mor- 
tality (8-10), but also because of the health disparities of Latinos in the United States. Compared to nonLatino whites, Latinos suffer from more age-adjusted years of potential life lost per 100000 population because of a number of obesity-related diseases such as diabetes, heart disease, stroke, and cancer (3). Also, their access to health care and the quality of care lag considerably behind those enjoyed by non-Latino whites (4).

Despite these health disparities, most studies of obesity among Latinos in the United States either fail to present data on Latinos (9-11), or tend to aggregate data across Latino subgroups, ignoring the potential heterogeneity that exists within these populations $(8,12,13)$. Combining groups into one category ignores potentially important differences that may exist between individuals of different Latino nationalities. Studies that present data on a specific (7) or several (14) Latino nationalities have made an important contribution to our understanding of the epidemiology of obesity and risk factors in these populations. For example, the intake of total fat, saturated fat, monosaturated fat, and carbohydrates varied considerably according to the participants' Latino background, gender, and age (14). These findings illustrate important differences that can be identified when Latino groups are studied separately. However, to our knowledge, in the United States very few studies have focused on a single subgroup or on multiple Latino subgroups, and those that have done so were generally based on small samples, were restricted to a particular community or city, or were based on outdated data (e.g., 1982-1984 Hispanic Health and Nutrition Examination Survey) (15). These limitations prevent the findings from being current or generalizable to Latinos in a country where they have become the largest $\mathrm{racial} / \mathrm{ethnic} \mathrm{mi}$ nority group.

In this study we addressed some of the limitations of prior research, and sought to increase our knowledge by specifically examining differences in the prevalence of overweight among boys and girls of Mexican-American, Puerto Rican, and other Latin American heritage, using large representative national samples. Also, we examined whether the differences in overweight could be accounted for by differences in socioeconomic status, lifestyle habits that may be associated with obesity such as fruit and vegetable consumption (16), exercising (17), amount of sleep (18), and amount of TV viewing (19) and family-parenting characteristics (20) found in prior research to be associated with increased risk of overweight and obesity.

\section{MATERIALS AND METHODS}

\section{Sample}

This study used 1991-2004 data from 8th and 10th grade adolescents who participated in the annual University of Michigan's Monitoring the Future surveys. Data for 12th grade youth were not included here because several variables under investigation were not included in all versions of the multiple-form questionnaire, precluding multivariate analyses with all relevant variables. The design and methods are summarized briefly below; a detailed description is available elsewhere (21).

The study used a multistage sampling design to obtain independent, nationally representative samples of 8 th and 10th grade students from the 48 contiguous states of the United States. The procedure used for each annual sample consisted of three stages (22): first, geographic regions were selected; second, schools were randomly selected with probability proportionate to size (approximately 290 each year); third, roughly 31000 to 33000 students were sampled from these schools. Sample weights were assigned to each student to take into account variations in selection probabilities that occurred at different stages of sampling. Students completed a self-administered, machine-readable questionnaire during a normal class period. Student response rates averaged $90 \%$ for 8 th graders and $86 \%$ for 10th graders. Absence on the day of data collection was the primary reason why students were missed.

\section{Measures}

Overweight. Age- and gender-specific growth curves produced by the Centers for Disease Control and Prevention were used to assign individuals to the "overweight" category, defined here as youth whose body mass index (BMI) was greater than or equal to the 85 th percentile $(23,24)$. These growth curves were normalized for data from several national health examination surveys conducted by the National Center for Health Statistics between 1963 and 1994. Body mass index was calculated by dividing self-reported weight (in kilograms) by height (in meters) squared (weight/height ${ }^{2}$ ).

Healthy eating habits. Three separate questions meant to be indicative of the frequency of healthy eating habits were asked in the present study: "How often do you eat breakfast?", "How often do you eat at least some green vegetables?", and "How often do you eat at least some fruit?" The response categories for all three were: 1 = never, 2 = seldom, $3=$ sometimes, $4=$ most days, 5 = nearly every day, and $6=$ every day. A composite score was created by summing the students' responses to these three questions; scores range from 3 to 18 . Cronbach's alpha was 0.69 for females and 0.71 for males.

Exercising habits. The variable for frequency of exercising was based on the question "How often do you exercise vigorously (jogging, swimming, calisthenics, or any other active sports)?" The response categories were the same as for eating habits.

Sleeping habits. The question "How often do you get at least seven hours of sleep?" had the same answer scale as the eating habits questions. 
Television viewing. The average number of hours that youth watch television in an average week was recorded based on the following two questions: "How much TV do you estimate you watch on an average WEEKDAY?" and "How much TV do you estimate you watch on an average WEEKEND (both Saturday and Sunday combined)?" The number of viewing hours in a week (5 days) and in a weekend were added, and the sums ranged from 0 to $>34$ hours. The total was divided by seven to obtain the average number of hours per day.

Family characteristics. Four variables were included to study family characteristics. The variable "first language spoken" was studied by asking, "What was the first language you spoke when you were a child?", with the following categories: English, Spanish, or some other language. We excluded students who answered "some other language" because the number was very small $(1.4 \%)$. The variable "unsupervised time" was studied by asking, "On average, how much time do you spend after school each day at home with no adult present? (Count the hours between the end of school and when you go to bed)." The response categories were none or almost none, less than 1 hour, 1-2 hours, 2-3 hours, 3-5 hours, and more than 5 hours. The variable "family intactness" was used to record whether the adolescent lived with both parents (dichotomous variable). The variable "working mother" was used to record whether the adolescent's mother had a paid job (no, works part-time, works full-time).

Demographic characteristics. Gender was recorded with the question, "What is your sex?" ( $1=$ male, 2 = female). Race/ethnicity was recorded with the question, "How do you describe yourself?" For the present study three groups were distinguished: (a) Mexican-American, (b) Puerto Rican, and (c) other Latin American. Students of other Latin American backgrounds included those who indicated they were of Cuban, Central American, or South American background. Although a response category distinguished adolescents of Cuban heritage, the small sample size $(5 \%)$ precluded us from conducting a separate analysis for this group. Parental education (as a proxy for socioeconomic status) was defined as an average of the father's and mother's educational attainment (with one missing data case permitted). The categories of educational attainment for each parent were: 1 = completed grade school or less, 2 = some high school, 3 = completed high school, $4=$ some college, $5=$ completed college, and $6=$ graduate or professional school after college. Preliminary analyses showed that the relationship between this measure of average parental education and the dependent variable overweight was not linear. We therefore created a variable with three levels (low, mid, and high), and two dummy variables were used in the analyses.

Population density reflected the school's location within a large metropolitan statistical area, other metropolitan statistical area, or nonmetropolitan statistical area. Region was determined by the geographical region of the country where the school was located (i.e., Northeast, North Central, South, or West).

\section{Analyses}

Because of observed gender differences in the prevalence of overweight $(25,26)$, all analyses were conducted separately for boys and girls. Also, all analyses were based on the 8th and 10th grade data combined, because there were no meaningful differences by grade in the prevalence of overweight, or in the associations between variables. Five models were tested to examine whether differences in the percent of overweight adolescents changed as a function of their socioeconomic status, lifestyle habits, familyparenting, or demographic characteristic. Model 1 estimated the association (odds ratios) between each predictor (that is, only one predictor at a time was entered in the model) and overweight, while statistically controlling for grade level, population density, region, and year the survey took place. All these potential confounders were dummy-coded. Models 2, 3, and 4 added to Model 1, one at a time, the socioeconomic status, lifestyle habits, and family-parenting variables, respectively. The Full Model included all the variables entered simultaneously. We used the Stata 8.0 statistical program (Stata Corporation, College Station, Texas, United States) to estimate between-group differences in the weighted proportion of overweight adolescents, and to account for design effects in calculating variance estimates.

\section{RESULTS}

\section{Sample characteristics and percent overweight}

During the 14-year period from 1991 to 2004, a total of 11265 Latino students (5 274 boys and 5991 girls) completed the relevant questionnaire forms. Approximately $66 \%$ of the students were of Mexican-American ethnicity, $12 \%$ were of Puerto Rican ethnicity, and 22\% were of other Latin American ethnicities. Table 1 shows the percentage of overweight adolescents by demographic and familyparenting characteristics.

Girls of Mexican-American or Puerto Rican heritage were significantly more likely than girls of other Latin American heritage to be overweight. No significant differences were observed among boys. The percent of overweight students varied inversely with socioeconomic status for all youth, but these bivariate differences were not statistically significant. The percent of overweight students did not vary significantly by grade level, language first spoken, family intactness, mother's employment status, population density, or region.

There were a number of differences in the frequency with which adoles- 
TABLE 1. Percentage of overweight adolescents of Mexican-American, Puerto Rican, and other Latin American ethnicity, by demographic characteristics, among 8th and 10th grade students in the United States of America who participated in the annual Monitoring the Future surveys, 1991-2004

\begin{tabular}{|c|c|c|c|c|c|c|}
\hline \multirow[b]{2}{*}{ Characteristic } & \multicolumn{3}{|c|}{ Males } & \multicolumn{3}{|c|}{ Females } \\
\hline & $N$ & $\%$ overweight & Significance $^{a}$ & $N$ & $\%$ overweight & Significance $^{a}$ \\
\hline \multicolumn{7}{|l|}{ Grade level } \\
\hline Tenth & 2588 & 35.0 & & 3071 & 23.1 & \\
\hline Ethnicity & & & & & & $P<0.001$ \\
\hline Mexican-American & 3510 & 34.8 & & 3965 & 25.5 & \\
\hline Low & 1926 & 35.4 & & 2594 & 27.9 & \\
\hline Middle & 2692 & 34.9 & & 2804 & 22.6 & \\
\hline High & 656 & 27.7 & & 593 & 17.5 & \\
\hline \multicolumn{7}{|l|}{ Family/Parenting } \\
\hline \multicolumn{7}{|l|}{ Language first spoken } \\
\hline Spanish & 2475 & 34.7 & & 2948 & 25.1 & \\
\hline \multicolumn{7}{|l|}{ Working mother } \\
\hline No & 1248 & 36.0 & & 1614 & 23.9 & \\
\hline Part-time & 868 & 32.2 & & 1074 & 25.7 & \\
\hline Full-time & 3158 & 34.1 & & 3303 & 24.4 & \\
\hline \multicolumn{7}{|l|}{ Population density } \\
\hline Large $\mathrm{MSA}^{\mathrm{b}}$ & 1896 & 34.4 & & 2273 & 24.4 & \\
\hline Other-MSA & 2687 & 34.8 & & 2978 & 24.3 & \\
\hline Non-MSA & 691 & 31.9 & & 740 & 25.6 & \\
\hline \multicolumn{7}{|l|}{ Region } \\
\hline Northeast & 636 & 33.5 & & 750 & 25.8 & \\
\hline North Central & 528 & 33.4 & & 539 & 23.4 & \\
\hline South & 1665 & 35.3 & & 1803 & 25.7 & \\
\hline West & 2445 & 33.9 & & 2899 & 23.7 & \\
\hline
\end{tabular}

cents engaged in the health-related behaviors we studied (Table 2). Among boys, the mean frequency of eating breakfast, fruits, and vegetables was higher for those of other Latin American heritage than in those of MexicanAmerican heritage. Among girls, the frequency was higher in MexicanAmerican girls than in Puerto Rican girls, and was higher in those of other Latin American heritage compared to both Mexican-American and Puerto Rican girls. There were no differences between ethnicities in the mean frequency of sleeping at least seven hours a day in either boys or girls, or in the frequency of exercising vigorously in boys. Girls of Mexican-American and other Latin American heritage exercised more frequently than Puerto Rican girls. On average, boys and girls of other Latin American heritage spent the least time watching television, and those of Puerto Rican heritage watched the most.

\section{Multivariate results}

Model 1: Latino nationality and overweight. The odds ratios of the association between each predictor (taken singly) and overweight, estimated in Model 1, were adjusted for the poten- tial confounding effects of grade level in school, population density, region, and year the survey took place (Tables 3 and 4). For boys, the odds ratio was lower among those of other Latin American heritage compared to Mexican-American adolescents, even though the unadjusted percentages of overweight shown in Table 1 were not significantly different. (Subsequent analyses revealed that region was responsible for increasing the magnitude of this odds ratio.) There were no differences in overweight between boys of Puerto Rican and other Latin American backgrounds. Among girls, the odds ratios were again signifi- 
TABLE 2. Weighted mean differences (with standard error (SE)) in frequency of lifestyle habits by Latino ethnicity and gender in 8th and 10th grade students in the United States of America who participated in the annual Monitoring the Future surveys, 1991-2004

\begin{tabular}{|c|c|c|c|c|c|}
\hline $\begin{array}{l}\text { Frequency of engaging } \\
\text { in lifestyle habita }\end{array}$ & Scale & $\begin{array}{l}\text { Mexican- } \\
\text { American } \\
\text { Mean (SE) }\end{array}$ & $\begin{array}{c}\text { Puerto } \\
\text { Rican } \\
\text { Mean (SE) }\end{array}$ & $\begin{array}{l}\text { Other Latin } \\
\text { American } \\
\text { Mean (SE) }\end{array}$ & Significant contrasts ${ }^{b}$ \\
\hline \multicolumn{6}{|l|}{ Boys } \\
\hline $\begin{array}{l}\text { Eating breakfast, } \\
\text { fruits, and vegetables }\end{array}$ & $3-18$ & $11.70(0.09)$ & $12.06(0.19)$ & $12.23(0.12)$ & OLA vs. MA, $P<0.001$ \\
\hline Sleeping at least 7 hours & $1-6$ & $4.53(0.04)$ & $4.54(0.10)$ & $4.54(0.05)$ & None \\
\hline Exercising vigorously & $1-6$ & $4.55(0.03)$ & $4.55(0.07)$ & $4.54(0.10)$ & None \\
\hline $\begin{array}{l}\text { Daily number of hours } \\
\text { spent watching TV }\end{array}$ & $0-5$ & $2.87(0.05)$ & $3.04(0.08)$ & $2.73(0.04)$ & $\begin{array}{l}\text { PR vs. MA, } P<0.05 \\
\text { PR vs. } O L A, P<0.001 \\
\text { MA vs. OLA, } P<0.01\end{array}$ \\
\hline \multicolumn{6}{|l|}{ Girls } \\
\hline $\begin{array}{l}\text { Eating breakfast, } \\
\text { fruits, and vegetables }\end{array}$ & $3-18$ & $10.90(0.09)$ & $10.20(0.19)$ & $11.84(0.10)$ & $\begin{array}{l}\text { MA vs. } P R, P<0.001 \\
\text { OLA vs. } M A, P<0.001 \\
\text { OLA vs. } P R, P<0.001\end{array}$ \\
\hline Sleeping at least 7 hours & $1-6$ & $4.25(0.05)$ & $4.21(0.07)$ & $4.34(0.04)$ & None \\
\hline Exercising vigorously & $1-6$ & $3.93(0.06)$ & $3.70(0.09)$ & $4.02(0.05)$ & $\begin{array}{l}\text { MA vs. PR, } P<0.05 \\
\text { OLA vs. } P R, P<0.01\end{array}$ \\
\hline $\begin{array}{l}\text { Daily number of hours } \\
\text { spent watching TV }\end{array}$ & $0-5$ & $2.71(0.04)$ & $2.93(0.06)$ & $2.63(0.06)$ & $\begin{array}{l}\text { PR vs. MA, } P<0.001 \\
\text { PR vs. OLA, } P<0.001\end{array}$ \\
\hline
\end{tabular}

a For all lifestyle habits, the higher the number on the scale, the more frequently the behavior occurred.

${ }^{\mathrm{b}}$ The last column indicates significant differences in the particular lifestyle habit between the Hispanic ethnicities. MA = Mexican-American; PR = Puerto Rican; OLA = other Latin American.

cantly lower for those of other Latin American heritage compared to both Mexican-American and Puerto Rican girls. The odds ratio for the Puerto Rican and Mexican-American contrast did not differ significantly among girls.

Socioeconomic status was inversely associated with overweight, although for boys the difference in overweight between low and middle socioeconomic status was not significant. For girls, a significant difference was observed for both high-low and middle-low contrasts. The frequency of healthy eating, sleeping at least seven hours, and exercising vigorously was inversely associated with overweight among boys, and among girls this association was seen for frequency of healthy eating and exercising vigorously. The number of hours boys and girls spent each day watching television was positively associated with overweight. None of the family characteristics measuredlanguage first spoken, hours spent alone, family intactness, or mother's employment status-were associated with overweight.

Model 2: socioeconomic status and overweight. When socioeconomic status was added to Latino ethnicity in the model, the differences in overweight between boys and girls of
Latino heritage observed in Model 1 remained significant among girls (other Latin Americans were less likely to be overweight than MexicanAmerican and Puerto Rican girls), but not among boys (Tables 3 and 4). Socioeconomic status remained significantly associated with overweight among boys and girls, as observed in Model 1.

Model 3: health-related behaviors and overweight. When the health-related behavior variables were added to the model, the differences in overweight between boys and girls of different Latino heritage observed in Model 1 remained significant among girls, but 
TABLE 3. Results of multiple logistic regression analyses to predict overweight among adolescent males of Mexican-American, Puerto Rican, and other Latin American ethnicity in 8th and 10th grade students in the United States of America who participated in the annual Monitoring the Future surveys, 1991-2004

\begin{tabular}{|c|c|c|c|c|c|c|c|c|c|c|}
\hline \multirow[b]{2}{*}{ Variable $^{a}$} & \multicolumn{2}{|c|}{ Model $1^{b}$} & \multicolumn{2}{|c|}{ Model $2^{\mathrm{c}}$} & \multicolumn{2}{|c|}{ Model $3^{c}$} & \multicolumn{2}{|c|}{ Model $4^{c}$} & \multicolumn{2}{|c|}{ Full Model ${ }^{c}$} \\
\hline & $\begin{array}{l}\text { Odds } \\
\text { ratio }^{d}\end{array}$ & $95 \% \mathrm{Cl}^{\mathrm{e}}$ & $\begin{array}{l}\text { Odds } \\
\text { ratio }\end{array}$ & $95 \% \mathrm{Cl}$ & $\begin{array}{l}\text { Odds } \\
\text { ratio }\end{array}$ & $95 \% \mathrm{Cl}$ & $\begin{array}{l}\text { Odds } \\
\text { ratio }\end{array}$ & $95 \% \mathrm{Cl}$ & $\begin{array}{l}\text { Odds } \\
\text { ratio }\end{array}$ & $95 \% \mathrm{Cl}$ \\
\hline Mexican-American & 1.00 & - & 1.00 & - & 1.00 & - & 1.00 & - & 1.00 & - \\
\hline Puerto Rican & 0.95 & $0.75-1.21$ & 0.99 & $0.77-1.27$ & 0.99 & $0.79-1.23$ & 0.97 & $0.78-1.21$ & 1.01 & $0.78-1.28$ \\
\hline Other Latin American & 0.85 & $0.74-0.97$ & 0.89 & $0.78-1.02$ & 0.88 & $0.75-1.03$ & 0.85 & $0.72-0.99$ & 0.91 & $0.79-1.06$ \\
\hline High & 0.56 & $0.46-0.69$ & 0.69 & $0.55-0.87$ & & & & & 0.75 & $0.63-0.89$ \\
\hline \multicolumn{11}{|l|}{ Health-related behaviors } \\
\hline Healthy eating frequency & 0.96 & $0.91-0.97$ & & & 0.98 & $0.96-0.99$ & & & 0.98 & $0.95-1.00$ \\
\hline Sleeping frequency & 0.92 & $0.89-0.96$ & & & 0.97 & $0.93-1.02$ & & & 0.97 & $0.90-1.04$ \\
\hline Exercise frequency & 0.89 & $0.86-0.92$ & & & 0.92 & $0.89-0.96$ & & & 0.95 & $0.91-0.98$ \\
\hline TV-viewing frequency & 1.06 & $1.02-1.11$ & & & 1.05 & $1.00-1.10$ & & & 1.05 & $1.01-1.09$ \\
\hline Hours spent alone & 1.01 & $0.97-1.05$ & & & & & 1.01 & $0.97-1.05$ & 1.01 & $0.96-1.06$ \\
\hline \multicolumn{11}{|l|}{$\begin{array}{l}\text { Family intactness } \\
\text { (lives with } 2 \text { parents) }\end{array}$} \\
\hline No & 1.00 & - & & & & & 1.00 & - & 1.00 & - \\
\hline Yes & 1.00 & $0.88-1.14$ & & & & & 1.01 & $0.88-1.15$ & 1.13 & $0.98-1.31$ \\
\hline \multicolumn{11}{|l|}{ Working mother } \\
\hline No & 1.00 & - & & & & & 1.00 & - & 1.00 & - \\
\hline Part-time & 0.83 & $0.69-1.00$ & & & & & 0.84 & $0.70-1.01$ & 0.85 & $0.72-1.00$ \\
\hline Full-time & 0.92 & $0.80-1.06$ & & & & & 0.93 & $0.80-1.07$ & 0.91 & $0.74-1.14$ \\
\hline
\end{tabular}

not boys (Tables 3 and 4). Among boys, the variables frequency of eating breakfast, fruits, and vegetables and frequency of exercising remained significantly associated with overweight. The slight attenuation of the odds ratios between Models 1 (odds ratio = 1.06) and 3 (odds ratio $=1.05$ ) for the association between overweight and television viewing frequency resulted in loss of statistical significance for this association. Among girls, overweight was inversely associated with exercise frequency, and positively associated with the number of hours of television they watched per day.
Model 4: family characteristics and overweight. Including in the model the family characteristics studied here did not change the differences observed among Latino ethnicities in boys or girls (Tables 3 and 4). These variables were not associated with overweight, with the possible exception of mother's part-time employment, which approached significance for boys.

Full model: Latino ethnicity and overweight by socioeconomic status, health-related behaviors, and family characteristics. When all the variables were entered in the model simultane- ously, the odds ratios associated with differences in overweight between Latino ethnicities became nonsignificant for boys, as expected given the findings with Models 2 and 3. However, the differences persisted among girls. Among both boys and girls, differences in overweight associated with socioeconomic status remained statistically significant. The frequency of vigorous exercising and the number of hours spent watching television remained significantly associated with overweight despite the large number of variables entered in the model for all adolescents. The magnitude of 
TABLE 4. Results of multiple logistic regression analyses to predict overweight among adolescent females of Mexican-American, Puerto Rican, and other Latin American ethnicities in 8th and 10th grade students in the United States of America who participated in the annual Monitoring the Future surveys, 1991-2004

\begin{tabular}{|c|c|c|c|c|c|c|c|c|c|c|}
\hline \multirow[b]{2}{*}{ Variable $^{a}$} & \multicolumn{2}{|c|}{ Model $1^{\mathrm{b}}$} & \multicolumn{2}{|c|}{ Model $2^{c}$} & \multicolumn{2}{|c|}{ Model $3^{c}$} & \multicolumn{2}{|c|}{ Model $4^{c}$} & \multicolumn{2}{|c|}{ Full Model $^{\mathrm{C}}$} \\
\hline & $\begin{array}{l}\text { Odds } \\
\text { ratio }^{d}\end{array}$ & $95 \% \mathrm{Cl}^{\mathrm{e}}$ & $\begin{array}{l}\text { Odds } \\
\text { ratio }\end{array}$ & $95 \% \mathrm{Cl}$ & $\begin{array}{l}\text { Odds } \\
\text { ratio }\end{array}$ & $95 \% \mathrm{Cl}$ & $\begin{array}{l}\text { Odds } \\
\text { ratio }\end{array}$ & $95 \% \mathrm{Cl}$ & $\begin{array}{l}\text { Odds } \\
\text { ratio }\end{array}$ & $95 \% \mathrm{Cl}$ \\
\hline Mexican-American & 1.00 & - & 1.00 & - & 1.00 & - & 1.00 & - & 1.00 & - \\
\hline Puerto Rican & 0.95 & $0.74-1.21$ & 1.03 & $0.80-1.32$ & 0.92 & $0.74-1.16$ & 0.93 & $0.75-1.17$ & 0.97 & $0.77-1.24$ \\
\hline Other Latin American & 0.64 & $0.53-0.78$ & 0.71 & $0.59-0.85$ & 0.70 & $0.59-0.83$ & 0.65 & $0.56-0.78$ & 0.70 & $0.58-0.85$ \\
\hline \multicolumn{11}{|l|}{ Socioeconomic status } \\
\hline High & 0.51 & $0.40-0.64$ & 0.56 & $0.44-0.73$ & & & & & 0.66 & $0.52-0.85$ \\
\hline \multicolumn{11}{|l|}{ Health-related behaviors } \\
\hline Healthy eating frequency & 0.96 & $0.95-0.98$ & & & 0.99 & $0.97-1.01$ & & & 1.00 & $0.98-1.02$ \\
\hline Sleeping frequency & 0.97 & $0.93-1.01$ & & & 1.02 & $0.97-1.06$ & & & 0.98 & $0.94-1.02$ \\
\hline Exercise frequency & 0.86 & $0.83-0.89$ & & & 0.88 & $0.84-0.92$ & & & 0.88 & $0.82-0.94$ \\
\hline TV-viewing frequency & 1.15 & $1.10-1.20$ & & & 1.16 & $1.07-1.17$ & & & 1.13 & $1.07-1.19$ \\
\hline Hours spent alone & 1.01 & $0.98-1.05$ & & & & & 1.01 & $0.97-1.05$ & 1.01 & $0.97-1.06$ \\
\hline \multicolumn{11}{|l|}{$\begin{array}{l}\text { Family intactness } \\
\text { (lives with } 2 \text { parents) }\end{array}$} \\
\hline No & 1.00 & - & & & & & 1.00 & - & 1.00 & - \\
\hline Yes & 0.88 & $0.77-1.01$ & & & & & 0.89 & $0.77-1.01$ & 0.88 & $0.74-1.04$ \\
\hline \multicolumn{11}{|l|}{ Working mother } \\
\hline No & 1.00 & - & & & & & 1.00 & - & 1.00 & - \\
\hline Part-time & 1.01 & $0.84-1.21$ & & & & & 1.04 & $0.86-1.24$ & 1.17 & $0.99-1.37$ \\
\hline Full-time & 0.99 & $0.86-1.14$ & & & & & 1.02 & $0.88-1.18$ & 1.10 & $0.97-1.25$ \\
\hline
\end{tabular}

${ }^{a}$ All analyses were adjusted for population density, region, grade level, and the year when the survey took place; all of these variables were dummy-coded.

b Variables were entered one at a time.

${ }^{\mathrm{c}}$ All variables were entered simultaneously.

d Odds ratios with $95 \% \mathrm{Cl}$ that do not capture the null (1.0) are statistically significant.

e $95 \% \mathrm{Cl}=95 \%$ confidence interval of the odds ratio.

these associations remained fairly similar across the models.

\section{DISCUSSION}

The major finding from these analyses is that Mexican-American and Puerto Rican girls surveyed between 1991 and 2004 were more likely than other Latin American girls to be overweight. This association between ethnicity and likelihood of overweight held even after socioeconomic status, health-related behaviors, selected family characteristics, and demographic variables were controlled for. Other Latin American boys were less likely to be overweight than MexicanAmerican and Puerto Rican boys before socioeconomic status, healthrelated behaviors, and family characteristics were controlled for, but the differences became nonsignificant after we controlled for these factors. The association between overweight and Latino heritage was attenuated for both boys and girls when socioeconomic status and health-related behavior variables were entered in the model; family characteristics did not affect the associations between Latino ethnicity and overweight. We also found several differences between Latino ethnicities in the frequency with which adolescents engaged in the health-related behaviors studied. The family characteristics examined in this study were not associated with overweight.

Before further discussing the study's findings, the following limitations should be considered. First, data were not available on caloric intake and the family's eating and physical activity routines. Second, the data were based on self-reports, which may have resulted in underestimation of BMI (27). 
We do not believe this potential downward bias had a substantial effect on the associations we found, because these biases were likely to be relatively constant across groups. Also, we believe that because most underreporting occurs among those with the highest BMIs (27-29), most of these adolescents were probably correctly classified as overweight based on the definition used in the present study, and this would reduce the likelihood of bias in the estimated odds ratios. The slight bias towards underreporting weight appeared to be small enough to accept the conclusions as reliable (27-29). The use of self-reported data may also introduce artifactual differences between the genders in overweight rates, but by analyzing each gender separately we avoided this potential source of bias. Finally, by lumping adolescents into the other Latin American category because of small sample sizes, we lost information that might have shed light on the distribution of obesity in the different groups in this category.

These limitations notwithstanding, this study has some important strengths. First, we used data from large representative national samples of adolescents from the two largest Latino populations in the United States, i.e., Mexican-Americans and Puerto Ricans. Second, a fairly large number of variables that tap into several domains (e.g., sociodemographics, health-related behaviors, and family characteristics) were included in the analyses. Third, our sampling strategy allowed us to perform a number of analyses that could not have been done with smaller samples.

In the present study, we provide evidence of the importance of the individual's social location, as evidenced by the finding that socioeconomic status eliminated, for boys, and attenuated, for girls, the differences in the percentage of overweight students observed between Latino ethnicities. We also identified two potentially modifiable health-related behaviors that were associated with overweight even after a large number of potential confounders were entered in the model: frequency of vigorous exercise and time spent watching television per day. The findings that youth who exercised less frequently and those who spent more time watching television (a sedentary activity) were more likely to be overweight is consistent with prior research $(17,19)$. Yet it appears that in general, opportunities to engage in physical activity are not lacking for Latinos. A recent national study found that communities with large Latino populations had more settings available to engage in physical activity (e.g., sports areas, public pools and beaches, parks and green spaces, bike paths and lanes) than communities with predominantly white and black populations (30). These findings were significant even after adjustment for potential confounders such as household income, population density, and region. Clearly, more research is needed to determine ways to increase the levels of physical activity among young Latinos who may already have access to spaces for physical activity.

The frequency with which youth eat breakfast, fruits, and vegetables regularly was inversely associated with overweight when grade level, population density, region, and survey year were accounted for. However, in subsequent models when other health-related behaviors were included simultaneously (see Model 3 and Full Model in Tables 3 and 4), the healthy eating variable was no longer significant. Further analyses revealed that it was the association with physical exercise and television viewing that attenuated the odds ratios for the association between the eating variable and overweight. It seems that adolescents who exercise more frequently and watch less television may have healthier eating patterns.
The frequency with which youth get at least seven hours of sleep per day was inversely associated with overweight in the initial model only for boys, but the association was attenuated in subsequent models. The steady decline with time in the percentage of youth who sleep at least seven hours per day on a regular basis $(25,26)$ suggests the need for further investigation into the effects of decreased sleep on youth eating and physical activity patterns. Finally, the lack of association between family characteristics and overweight points to the important role that Latino caregivers play in meeting the nutritional and physical needs of adolescents to prevent or reduce overweight, regardless of familial and parenting circumstances. More research is needed on family characteristics such as eating and physical activity patterns to further understand how Latino families can help prevent and reduce obesity among adolescents.

Overweight and obesity among Latino youth in the United States is a serious problem that is manifested at an early age (31). In this study, we identified two potentially modifiable risk factors for both boys and girls. If targeted, increased physical activity and reduced television viewing may result in important reductions in overweight and obesity. Because we also found gender and ethnic differences in the frequency with which youth engaged in certain lifestyle habits, interventions aimed at increasing physical activity and reducing television viewing need to take into account the gender and cultural background of the targeted population, particularly among low-income youth, in whom the likelihood of being overweight was greatest.

Acknowledgment. This research was supported by grant 037769 from the Robert Wood Johnson Foundation, and grant DA01411 from the National Institute on Drug Abuse. 


\section{REFERENCES}

1. U.S. Census Bureau. Population estimates. Available from: http://www.census.gov/ popest/estimates.php. Accessed 22 March 2005.

2. U.S. Census Bureau. Income, poverty, and health Insurance coverage in the United States: 2003. P60-225. Available from: http:/ / www.census.gov/prod/2004 pubs/p60226.pdf. Accessed 22 March 2005

3. Centers for Disease Control and Prevention. Health disparities experienced by Hispanics: United States. MMWR. 2004;53(40):935-7.

4. Centers for Disease Control and Prevention. Access to health-care and preventive services among Hispanics and non-HispanicsUnited States, 2001-2002. MMWR. 2004; 53(40):937-41.

5. Jollife D. Extent of overweight among US children and adolescents from 1971 to 2000 . Int J Obes. 2004;28:4-9.

6. Delva J, O'Malley PM, Johnston LD. Racial/ ethnic and socioeconomic status differences in overweight and health-related behaviors among American students: National trends 1986-2003.J Adolesc Health. 2006;39(4):536-45.

7. Ogden CL, Carroll MD, Curtin LR, McDowell MA, Tabak CJ, Flegal KM. Prevalence of overweight and obesity in the United States, 1999-2004. JAMA. 2006;295:1549-55.

8. Flegal KM, Graubard BI, Williamson DF, Gail $\mathrm{MH}$. Excess deaths associated with underweight, overweight, and obesity. JAMA. 2005; 293:1861-7.

9. Olshansky SJ, Passaro DJ, Hershow RC, Layden J, Carnes BA, Brody J, et al. A potential decline in life expectancy in the United States in the 21st century. N Engl J Med. 2005;352: 1138-45.

10. Dietz WH. Health consequences of obesity in youth: childhood predictors of adult disease. J Pediatr. 1998;105:518-25.

11. Campaigne BN, Morrison JA, Schumann BC, Falkner F, Lakatos E, Sprecher D, et al. Indexes of obesity and comparisons with previous national survey data in 9- and 10-year old black and white girls: National Heart, Lung, and Blood Institute Growth and Health Study. J Pediatr. 1994;124:675-80.

12. Goel MS, McCarthy EP, Phillips RS, Wee CC. Obesity among US immigrant subgroups by duration of residence. JAMA. 2004;292: 2860-7.

13. Swallen KC Reither EN, Haas SA, Meir AM. Overweight, obesity, and health-related quality of life among adolescents: the National Longitudinal Study of Adolescent Health. Pediatr. 2005;115:340-7.

14. Loria CM, Bush TL, Carroll MD, Looker AC, McDowell MA, Johnson CL, et al. Macronutrient intakes among adult Hispanics: a comparison of Mexican Americans, Cuban Americans, and mainland Puerto Ricans. Am J Public Health. 1995;85:684-9.

15. U.S. Centers for Disease Control and Prevention. Hispanic Health and Nutrition Examination Survey, (HHANES). Available from: http:/ / www.cdc.gov/nchs/about/major/ nhanes/datalink.htm\#HHANES. Accessed 27 May 2005.

16. Neumark-Sztainer D, Story M, Resnick MD, Blum RW. Correlates of inadequate fruit and vegetable consumption among adolescents. Prev Med. 1996;25:497-505.

17. Vandewater EA, Shim M, Caplovitz AG. Linking obesity and activity level with children's television and video game use. J Adolesc. 2004;27:71-85.

18. Serkine M, Yamagani T, Handa K, Saito T, Nanri S, Kawaminami K, et al. A doseresponse relationship between short sleeping hours and childhood obesity: results of the Toyama Birth Cohort Study. Child Care Health Dev. 2002;28:163-70.

19. Crespo CJ, Smit E, Troiano RP, Bartlett SJ, Macera CA, Andersen RE. Television watching, energy intake, and obesity in US children: results from the Third National Health and Nutrition Examination Survey, 1988-1994. Arch Pediatr Adolesc Med. 2001;55:360-5.

20. Smedley BD, Stith AY, Alan R. Nelson AR, eds. Institute of Medicine Committee on Understanding and Eliminating Racial and Ethnic Disparities in Health Care. Unequal treatment: confronting racial and ethnic disparities in health care. Washington, D.C.: National Academy Press; 2002.

21. Johnston LD, O'Malley PM, Bachman JG, Schulenberg JE. Monitoring the Future national survey results on drug use, 1975-2004. Volume I: Secondary school students. Be- thesda: National Institute on Drug Abuse; 2005. (NIH Publication No. 05-5727).

22. Kish L. Survey sampling. New York: John Wiley \& Sons; 1965.

23. Hammer LD, Kraemer HC, Wilson DM, Ritter PL, Dornbusch SM. Standardized percentile curves of body-mass index for children and adolescents. Am J Dis Child. 1991;145:259-63.

24. Pietrobelli A, Faith MS, Allison DB, Gallagher D, Chiumello G, Heymsfield SB. Body mass index as a measure of adiposity among children and adolescents: a validation study. J Pediatr. 1998;132:204-10.

25. Delva J, Johnston LD, O'Malley PO. Obesity and lifestyle habits among American adolescents: a study of SES, gender, and racial/ ethnic differences 1986-2003. Ann Arbor: Institute for Social Research.

26. Johnston LD, O'Malley PO. Obesity among American adolescents: tracking the problem and searching for causes. Ann Arbor: Institute for Social Research; 2003.

27. Brener ND, McManus T, Galuska DA, Lowry $\mathrm{R}$, Wechsler H. Reliability and validity of selfreported height and weight among high school students. J Adolesc Health. 2003;32: 281-7.

28. Goodman E, Hinden BR, Khandelwal S. Accuracy of teen and parental reports of obesity and body mass index. Pediatr. 2000;106:52-8.

29. Strauss RS. Comparison of measured and selfreported weight and height in a crosssectional sample of young adolescents. Int J Obes. 1999;23:904-8.

30. Powel LM, Slater S, Chaloupka FJ. The relationship between community physical activity settings and race, ethnicity and socioeconomic status. Evidence-Based Prev Med. 2004;1:135-44.

31. Beets MW, Pitetti KH. One-mile run/walk and body mass index of an ethnically diverse sample of youth. Med Sci Sports Exerc. 2004; 36:1796-803.

Manuscript received on 16 August 2005. Revised version accepted for publication on 11 September 2006. 
RESUMEN Objetivos. Analizar las diferencias, según el sexo, en el sobrepeso de adolescentes de origen mexicano, puertorriqueño y de otros países latinoamericanos que viven en los Estados Unidos de América e investigar la relación entre esas diferencias y el

Conductas relacionadas con la salud y sobrepeso: estudio en adolescentes latinoamericanos residentes en los Estados Unidos de América

Palabras clave estatus socioeconómico, las conductas relacionadas con la salud y las características familiares.

Métodos. En este estudio transversal por encuesta se obtuvieron y analizaron los datos de muestras representativas para el país de estudiantes latinoamericanos del $8 .^{\circ}$ y 10..$^{\circ}$ grados del estudio Monitoring the Future de 1991 a $2004(N=11265)$.

Resultados. Se observó una mayor proporción de niñas estadounidenses de origen mexicano con sobrepeso que de niñas latinoamericanas de otro origen, tanto antes como después de ajustar por numerosos factores de confusión. Independientemente del sexo, el sobrepeso estuvo asociado inversamente con el estatus socioeconómico y la frecuencia de los ejercicios físicos fuertes, y directamente asociado con el tiempo dedicado a ver televisión. No se encontró asociación entre el sobrepeso y las características familiares.

Conclusiones. El tiempo dedicado a realizar ejercicios y a ver televisión son dos factores susceptibles de modificar y, si se plantean como objetivo, se puede lograr una importante reducción del sobrepeso. Estos resultados demuestran la necesidad de identificar intervenciones apropiadas, desde el punto de vista cultural y según el sexo, que permitan aumentar la actividad física y reducir las actividades sedentarias en los adolescentes hispanoamericanos, especialmente en las familias de bajo estatus socioeconómico.

Aculturación, hispanoamericanos, americanos mexicanos, sobrepeso, obesidad, clase social, factores socioeconómicos, Estados Unidos.

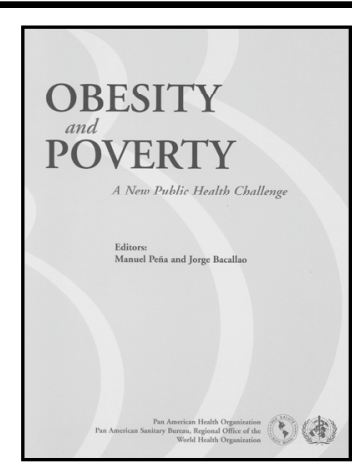

2000, 124 pp.,

ISBN 927511576

Order code: SP 576,

Price: US\$ 18.00 in Latin

America and the Caribbean/

US\$22.00 elsewhere

\section{Obesity and Poverty: A New Public Health Challenge}

Obesity and Poverty: A New Public Health Challenge is an essential source for understanding the new face of poverty in the Region of the Americas. This up-to-date examination of the prevalence of overweight and obesity in the Region's countries looks at these conditions' medium- and long-term harmful consequences and explores their implications for planning public health interventions.

The book analyzes how the Region's countries experience the nutritional transition process that is under way worldwide, a process that is tied to the global demographic and epidemiologic transition. In this context, the increase in obesity and overweight observed in the Hemisphere coexists with a risk factor that differs from traditional risk factors seen in developed countries - the persistence of the increase in inequalities and inequities in health.

http://publications.paho.org • Fax: (301) 206-9789・E-mail:paho@pmds.com 